\title{
ABUNDANCE OF CLADOCERANS IN THE LITTORAL REGIONS OF TWO ENVIRONMENTS OF THE UPPER PARANÁ RIVER FLOODPLAIN, MATO GROSSO DO SUL, BRAZIL
}

\author{
ROSSA, D. C., LANSAC-TÔHA, F. A., BONECKER, C. C. and VELHO, L. F. M. \\ Universidade Estadual de Maringá, DBI, Nupélia, PEA, Av. Colombo, 5790, CEP 87020-900, Maringá, PR, Brazil \\ Correspondence to: Dayane Christian Rossa, Nupélia, Universidade Estadual de Maringá, CEP 87020-900, \\ Maringá, PR, Brazil, e-mail: bonecker@ nupelia.uem.br. \\ Received December 14, 1998 - Accepted December 10, 1999 - Distributed February 28, 2001
}

(With 5 figures)

\begin{abstract}
The abundance of cladocerans recorded in plankton samples from the littoral regions of two enviroments (Baía River and Guaraná lake), the Upper Paraná River floodplain and some limnological variables important in controlling their abundance were investigated at three sites in the lake and two in the river, from March/93 to January/94. Abundance was highest in the lake, chiefly during high water. Bosminidae dominated in both environments and hydrological periods (high and low water). Chydoridae were more important in the lake, and Sididae in the river. A higher number of Pearson's correlations significative $(\mathrm{p}<0.03)$ between the densities of the ten most important species and the limnological variables was observed in the river. This suggests that limnological variables are more important in controlling the abundance of cladocerans in the river. On the other hand, in the lake their abundance was probably associated with the physical structure of the environment, the abundance of aquatic macrophytes, and biotic relationships such as competition and predation.
\end{abstract}

Key words: cladocerans, littoral, floodplain, tropical.

\section{RESUMO}

Abundância de cladóceros na região litoral de dois ambientes da planície de inundação do alto Rio Paraná, Mato Grosso de Sul, Brasil

A abundância de cladóceros no plâncton da região litorânea em dois ambientes (Rio Baía e Lagoa do Guaraná) da planície de inundação do alto Rio Paraná foi investigada, bem como a influência de algumas variáveis limnológicas sobre a densidade desses organismos em três estações na lagoa e duas no rio, no período de março/93 a janeiro/94. A maior abundância foi registrada na lagoa durante o período de águas altas. A família Bosminidae foi dominante em ambos os ambientes e períodos hidrológicos (águas altas e águas baixas). Chydoridae foi mais importante na lagoa e Sididae, no rio. Foi observado maior número de correlações de Pearson significativas $(p<0,03)$ entre as densidades das dez espécies numericamente mais importantes e das variáveis limnológicas no rio. Esses resultados sugerem que as variáveis limnológicas estudadas, provavelmente, influenciam mais na estrutura das populações de cladóceros no rio do que na lagoa. Por outro lado, outro fatores, como a estrutura física do ambiente ou a quantidade de vegetação presente nas margens, além das relações bióticas entre as populações, como competição e predação, parecem ser mais importantes para a dinâmica das principais espécies na lagoa.

Palavras-chave: cladóceros, litoral, planície de inundação. 


\section{INTRODUCTION}

The floodplain ecosystem consists of lakes, channels, and areas subject to flooding associated with large rivers (Junk, 1980). In this ecosystem, seasonal fluctuations in water level act as a forcing function which leads to changes in the physical and chemical characteristics of the water and consequent variations in the composition and abundance of the aquatic organisms (Junk et al., 1989; Thomaz et al., 1997).

Studies of floodplain cladocerans have mainly dealed with population fluctuation patterns determined by limnological changes caused by rises in water levels (Twombly \& Lewis, 1987; Paggi \& José De Paggi, 1990; Campos et al., 1996; LansacTôha et al., 1997; Lima et al., 1998). Most investigations have been done in the limnetic zone, although some studies have attempted to compare differences in abundance and composition of the cladocerans in littoral zones, influenced by the presence of aquatic macrophytes (Rybak et al., 1964; Smirnov \& Davis, 1973; Margaritora et al., 1975; Whiteside et al., 1978; Valdivia \& Zambrano, 1989; Paterson, 1993; Smirnov \& SantosSilva, 1995; Elías-Gutierrez et al., 1997).

The objective of the present investigation was to evaluate the abundance of cladocerans in plankton samples from the littoral zone of a lake and a river colonized by different banks of aquatic macrophytes, as well as to describe their temporal and spatial variations in relation to abiotic variables.

\section{STUDY AREA}

The Baía River $\left(22^{\circ} 43^{\prime} \mathrm{S}\right.$ and $\left.53^{\circ} 17^{\prime} \mathrm{W}\right)$ is located in the floodplain on the right bank of the Paraná River, in the State of Mato Grosso do Sul (Fig. 1). It is directly influenced by the hydrological regime of the Paraná. However, the low current velocity and slight slope of its bed allow it to be characterized as a floodplain river.

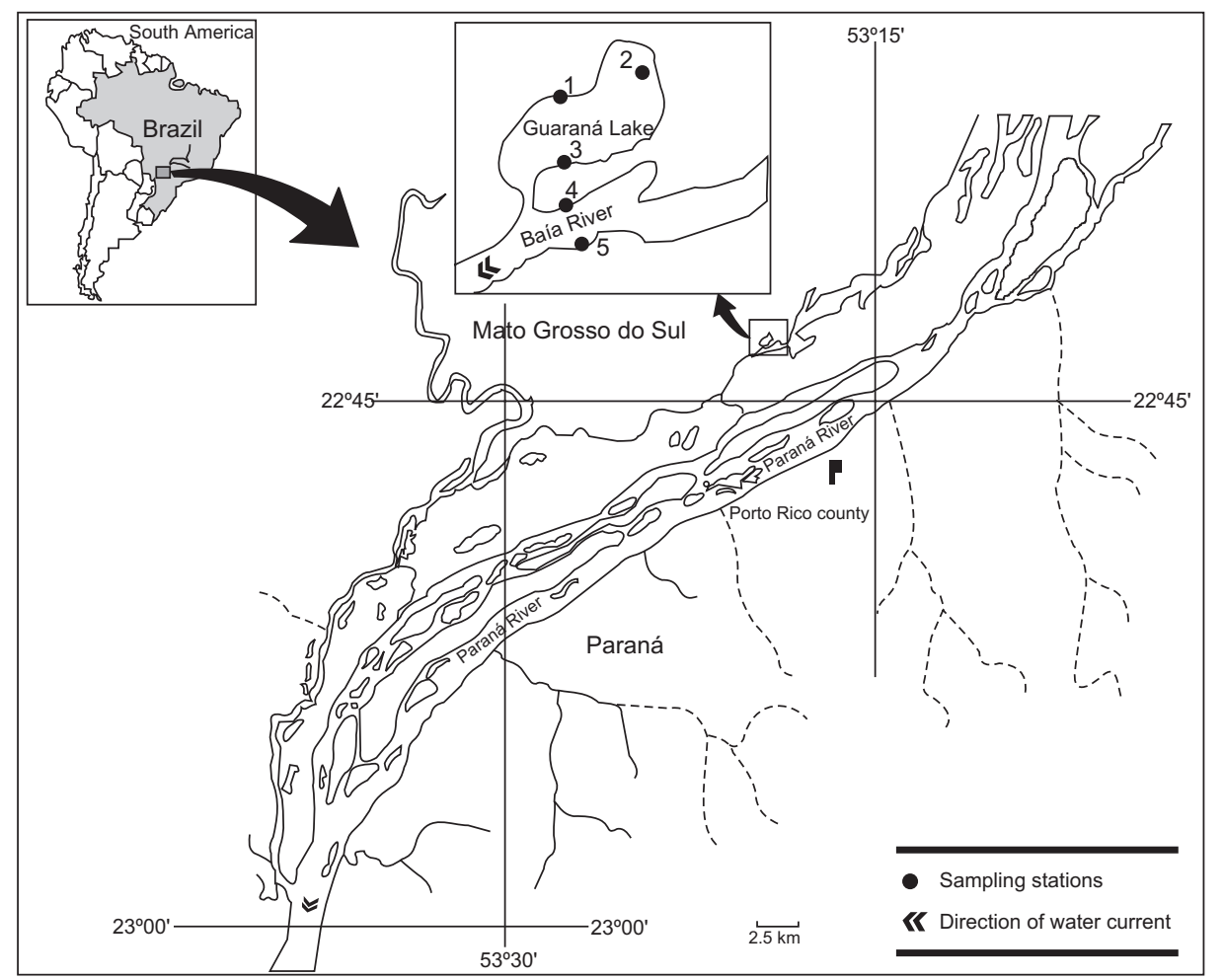

Fig. 1 - Location of the sampling stations in Guaraná Lake $(1,2,3)$ and the Baía River $(4,5)$. 
Guaraná Lake (2243’26"S and 53¹8’03"W) is located on the right bank of the Baía River, with which it is connected year-round. This connection is more pronounced during high water periods, apparently leading the system to behave more uniformly (Thomaz et al., 1992). Aquatic macrophytes, especially Eichhornia azurea (Swartz), predominate in the littoral zone.

For the purposes of this study, three sampling stations were established in the littoral zone of the lake: Stations 1 and 2 in locations with banks of aquatic macrophytes, and Station 3 in an area with a small quantity of vegetation; the predominant plant at all stations was E. azurea. There were two stations in the river: Station 4, without aquatic macrophytes; and Station 5 with macrophytes, mainly E. azurea.

\section{MATERIAL AND METHODS}

Environmental variables were measured and samples of cladocerans were taken at the five stations monthly during the morning, at the surface, from March/93 through January/94. The cladocerans were collected with a motorized pump, using a conical net (70 $\mu \mathrm{m}$ mesh) to filter 1,000 liters of water. The samples were preserved in a final solution of $4 \%$ formaldehyde, buffered with calcium carbonate. Analyses of the environmental variables, water temperature $\left({ }^{\circ} \mathrm{C}\right)$, transparency of the water column $(\mathrm{m})$, electrical conductivity ( $\mu \mathrm{S} /$ $\mathrm{cm})$, and dissolved oxygen concentration $(\mathrm{mg} / \mathrm{L})$ were performed according to the methods described by Thomaz et al. (1992).

The water levels of the Paraná River used in this work refer to the mean for the 14 days prior to each collection, following Thomaz et al. (1997). Daily water level values were provided by the National Department of Waters and Electrical Energy (DNAEE).

Qualitative and quantitative analyses of the cladocerans were carried out in the laboratory using standard and Sedgewick-Rafter slides and both compound and stereomicroscopes. Taxa were identified using the following references: Smirnov (1974, 1992), Korínek (1981), Paggi (1995), and Elmoor-Loureiro (1997). Abundance was estimated by counting at least 200 individuals per sample (ind $\left./ \mathrm{m}^{3}\right)$. ANOVA and Tukey's test were used to verify if there was significant difference in the abundance between station and hydrological period.
The differences in densities were significant if probability was $<0.05$. The analysis were carried out with the aid of the software Statistica Version 5.0 (Statsoft Inc., 1996).

A $\log (x+1)$ data matrix was constructed from the results for the environmental variables for the lake, and another for the river. The matrices were transformed by multinormalization, except for $\mathrm{pH}$. Principal components analysis (PCA) was used to reduce the dimensionality of the abiotic data. Variables for which structure coefficients $>0.8$ were considered important for explaining variability. The analysis was carried out with the aid of the software Statistica Version 5.0 (Statsoft Inc., 1996).

In order to establish the influence of the variables on the density of the main cladoceran species in each environment, we calculated Pearson's correlation coefficients between each of these densities and the environmental variables measured. Correlations were considered significant if their probability were $<0.05 /$ number of significance tests applied, according to Bonferroni's correction for multiple tests (Green, 1993). The software Statistica Version 5.0 (Statsoft Inc., 1996) was also used for this analysis.

\section{RESULTS}

\section{Limnological variables}

The results of the environmental variables obtained at the surface in the lake and the river are presented in Table 1 (FUEM PADCT-CIAMB, 1994).

\section{Fluviometric level}

From the mean water level of the Paraná River for the 14 days prior to each collection date, it was possible to establish two hydrological periods: high water (March and April/93 and January/94) and low water (May to December/93) (Fig. 2).

\section{Abundance}

In geral, higher mean densities of cladocerans were recorded in the lake, and lower densities in the river (Fig. 3), although their differences were not significative $(\mathrm{F}=2.358 ; \mathrm{p}=0.07)$. The most abundant species in both environments, together, were Bosminopsis deitersi (Bosminidae), Diaphanosoma birgei (Sididae), and Phryxura dadayi (Chydoridae). 
TABLE 1

Limnological variables (raw numbers, means, and SD) measured in the lake and river during March/93 to January/94 (PADCT-CIAMB/FUEM, 1994). $\mathrm{L}=$ water level, $\mathrm{T}=$ water temperature, $\mathrm{Tr}=$ water transparency, EC = electrical conductivity, and DO = dissolved oxygen.

\begin{tabular}{|c|c|c|c|c|c|c|c|c|c|c|c|c|c|}
\hline & $\mathbf{M}$ & $\mathbf{A}$ & $\mathbf{M}$ & $\mathbf{J}$ & $\mathbf{J}$ & $\mathbf{A}$ & $\mathbf{S}$ & $\mathbf{O}$ & $\mathbf{N}$ & D & $\mathbf{J}$ & Mean & SD \\
\hline $\mathrm{L}(\mathrm{cm})$ & 605 & 415 & 332 & 327 & 299 & 275 & 301 & 339 & 324 & 314 & 404 & 357 & 87,9 \\
\hline \multicolumn{14}{|c|}{ Lake } \\
\hline \multicolumn{14}{|l|}{ Station 1} \\
\hline $\operatorname{Tr}(\mathrm{m})$ & 1.7 & 0.9 & 1.20 & 1.10 & 1.0 & 0.07 & 0.8 & 0.07 & 0.7 & 0.77 & 1.7 & 1.01 & 0.4 \\
\hline $\mathrm{DO}(\% \mathrm{mg} / \mathrm{L})$ & 0.77 & 2.72 & 5.68 & 4.45 & 7.78 & 8.53 & 7.36 & 3.44 & 2.45 & 3.64 & 1.54 & 4.4 & 2.5 \\
\hline $\mathrm{T}\left({ }^{\circ} \mathrm{C}\right)$ & 29.9 & 25.9 & 19.2 & 17.3 & 21.1 & 20.1 & 23.4 & 26.9 & 21 & 22.9 & 22.2 & 22.7 & 3.5 \\
\hline $\mathrm{EC}(\mu \mathrm{S} / \mathrm{cm})$ & 43 & 30 & 22 & 22 & 22 & 22 & 24 & 33 & 29 & 24 & 45 & 28.7 & 8.1 \\
\hline $\mathrm{pH}$ & 6.5 & 6.2 & 6.1 & 5.6 & 5.8 & 6.3 & 6.2 & 5.5 & 5.5 & 5.7 & 6.0 & 5.9 & 2.5 \\
\hline \multicolumn{14}{|l|}{ Station 2} \\
\hline $\operatorname{Tr}(\mathrm{m})$ & 1.50 & 1.0 & 1.20 & 1.0 & 0.07 & 0.7 & 0.06 & 0.75 & 0.65 & 0.85 & 1.40 & 0.9 & 0.3 \\
\hline DO $(\% \mathrm{mg} / \mathrm{L})$ & 1.46 & 2.35 & 5.63 & 4.57 & 7.31 & 8.49 & 7.75 & 3.5 & 2.95 & 4.88 & 0.92 & 4.5 & 2.4 \\
\hline $\mathrm{T}\left({ }^{\circ} \mathrm{C}\right)$ & 30 & 26.5 & 19.4 & 16.8 & 21 & 20.1 & 23.7 & 26.8 & 23.1 & 23.7 & 22.2 & 23.0 & 3.6 \\
\hline $\mathrm{EC}(\mu \mathrm{S} / \mathrm{cm})$ & 39 & 27 & 22 & 22 & 22 & 21 & 25 & 33 & 29 & 24 & 45 & 28.0 & 7.5 \\
\hline $\mathrm{pH}$ & 6.4 & 6.2 & 6.2 & 5.7 & 6.1 & 6.5 & 6.5 & 5.9 & 5.7 & 6.2 & 6.1 & 6.1 & 0.3 \\
\hline \multicolumn{14}{|l|}{ Station 3} \\
\hline $\operatorname{Tr}(\mathrm{m})$ & 2.90 & 0.95 & 0 & 0.95 & 0 & 0.60 & 0.50 & 0.75 & 0.80 & 0.75 & 1.80 & 0.9 & 0.8 \\
\hline $\mathrm{DO}(\% \mathrm{mg} / \mathrm{L})$ & 2.03 & 3.02 & 6.57 & 5.04 & 6.29 & 8.62 & 8.51 & 3.91 & 3.37 & 5.66 & 2.22 & 5.0 & 2.2 \\
\hline $\mathrm{T}\left({ }^{\circ} \mathrm{C}\right)$ & 30.3 & 26.5 & 19.9 & 17.5 & 21.2 & 20.2 & 24.4 & 27 & 24.9 & 23.9 & 23 & 23.5 & $3 . .5$ \\
\hline $\mathrm{EC}(\mu \mathrm{S} / \mathrm{cm})$ & 43 & 30 & 23 & 24 & 22 & 21 & 24 & 33 & 29 & 23 & 46 & 28.9 & 8.2 \\
\hline $\mathrm{pH}$ & 6.7 & 6.3 & 6.1 & 5.6 & 6.0 & 6.3 & 6.4 & 5.6 & 5.7 & 6.0 & 6.1 & 6.1 & 0.3 \\
\hline \multicolumn{14}{|c|}{ River } \\
\hline \multicolumn{14}{|l|}{ Station 4} \\
\hline $\operatorname{Tr}(\mathrm{m})$ & 1.60 & 0.50 & 0 & 0 & 1.05 & 0.85 & 0.75 & 0.95 & 0.95 & 0.85 & 1.35 & 0.8 & 0.5 \\
\hline $\mathrm{DO}(\% \mathrm{mg} / \mathrm{L})$ & 2.74 & 7.75 & 6.94 & 7.54 & 8.33 & 9.74 & 9.37 & 7.24 & 8.05 & 7.29 & 7.69 & 7.5 & 1.7 \\
\hline $\mathrm{T}\left({ }^{\circ} \mathrm{C}\right)$ & 32.5 & 27.6 & 21 & 18 & 22.6 & 20.6 & 23.8 & 27.7 & 24.8 & 24 & 23.9 & 24.2 & 3.8 \\
\hline $\mathrm{EC}(\mu \mathrm{S} / \mathrm{cm})$ & 35 & 23 & 20 & 18 & 21 & 20 & 24 & 27 & 25 & 22 & 45 & 25.5 & 7.6 \\
\hline $\mathrm{PH}$ & 6.7 & 6.7 & 7.0 & 6.0 & 6.3 & 7.6 & 7.4 & 6.3 & 6.6 & 6.9 & 6.9 & 6.8 & 0.5 \\
\hline \multicolumn{14}{|l|}{ Station 5} \\
\hline $\operatorname{Tr}(\mathrm{m})$ & 1.95 & 1.02 & 0 & 0 & 0 & 0.75 & 0.65 & 0 & 0.80 & 0.80 & 1.40 & 0.7 & 0.6 \\
\hline $\mathrm{DO}(\% \mathrm{mg} / \mathrm{L})$ & 4.75 & 6.62 & 8.8 & 7.4 & 8.85 & 1063 & 9.15 & 7.84 & 8.07 & 7.84 & 6.79 & 7.8 & 1.5 \\
\hline $\mathrm{T}\left({ }^{\circ} \mathrm{C}\right)$ & 31.9 & 27.6 & 21.3 & 18.7 & 22.7 & 20.9 & 25.4 & 28.8 & 25.1 & 24.2 & 24.8 & 24.7 & 3.6 \\
\hline $\mathrm{EC}(\mu \mathrm{S} / \mathrm{cm})$ & 38 & 24 & 19 & 17 & 20 & 25 & 22 & 27 & 26 & 23 & 46 & 26.1 & 8.2 \\
\hline $\mathrm{PH}$ & 7.0 & 6.5 & 6.8 & 6.0 & 6.5 & 8.7 & 7.1 & 6.4 & 6.7 & 7.1 & 7.0 & 6.9 & 0.6 \\
\hline
\end{tabular}

The abundance of the families of cladocerans in each environment and in the two hydrological periods (high and low water) are seen in Fig. 4. The results for the ANOVA and Tukey's test showed that the environments differed significantly regarding to the Bosminide and Chydoridae abundances (ANOVA $-\mathrm{F}=4.354, \mathrm{p}=0.04 ; \mathrm{F}=10.289, \mathrm{p}=$ 0.002 , and Tukey's test $-p=0.024, p=0.002$, respectively). The cladocerans densities were not significantly different between hydrological periods. 


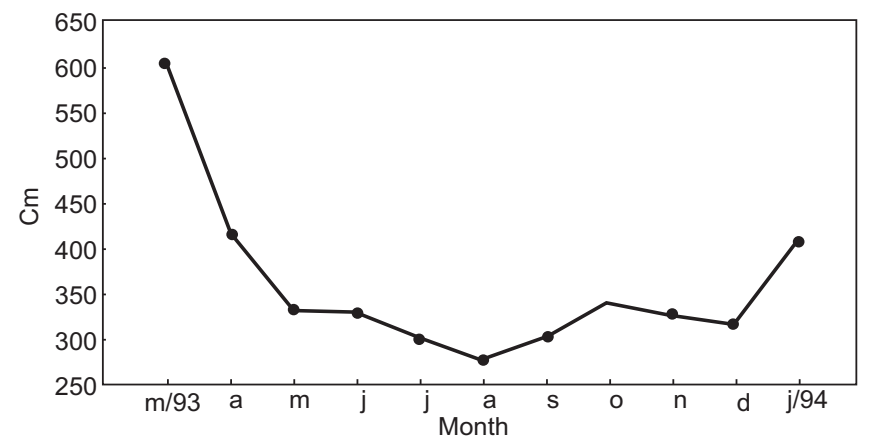

Fig. 2 - Variation in water level of the Paraná River (14-day means prior to each collection date), from March/93 to January 94.

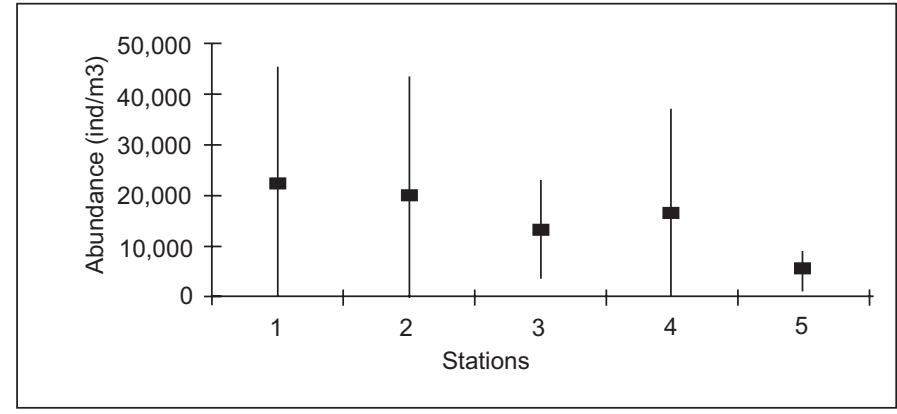

Fig. 3 - Mean (m) and standard deviation of abundance of cladocerans recorded in the lake (Stations 1, 2, 3) and the river (Stations 4, 5) from March/93 to January/94.

Of the seven families recorded, Bosminidae was most representative at all stations, followed by Chydoridae in the lake and Sididae in the river. Moinidae, represented especially by Moina minuta, was the least abundant family in both environments. Other families contributing importantly to total cladoceran density were Daphnidae and Ilyocryptidae. Ceriodaphnia cornuta and Ilyocryptus spinifer were the most abundant species of these families.

\section{Principal component analysis}

The PCA results showed that the first two axes explained $78.29 \%$ of the data variability (Fig. $5)$. The first axis explained most $(56.20 \%)$ of this variability, and was formed negatively by dissolved oxygen $(\mathrm{sc}=0.82)$, and positively by electrical conductivity $(\mathrm{sc}=0.91)$, water level $(\mathrm{sc}=0.90)$, and water transparency $(\mathrm{sc}=0.75)$. The second axis contributed $22.09 \%$, with a positive influence from $\mathrm{pH}(\mathrm{sc}=0.95)$.

These results indicate that $\mathrm{PC} 1$ reflected the seasonal variation of the data, since water level was one of the most important variables forming this axis. During high water, both environments showed higher values for water transparency, electrical conductivity, and temperature, and lower dissolved oxygen content. Higher dissolved oxygen contents were recorded during low water.

The spatial segregation of the environments observed along PC2 was established with $\mathrm{pH}$ values.

The distribution of the scores along the two axes showed that during high water, variation among values for limnological parameters was lower. During low water the values for these parameters differed more between the environments (Fig. 5). 


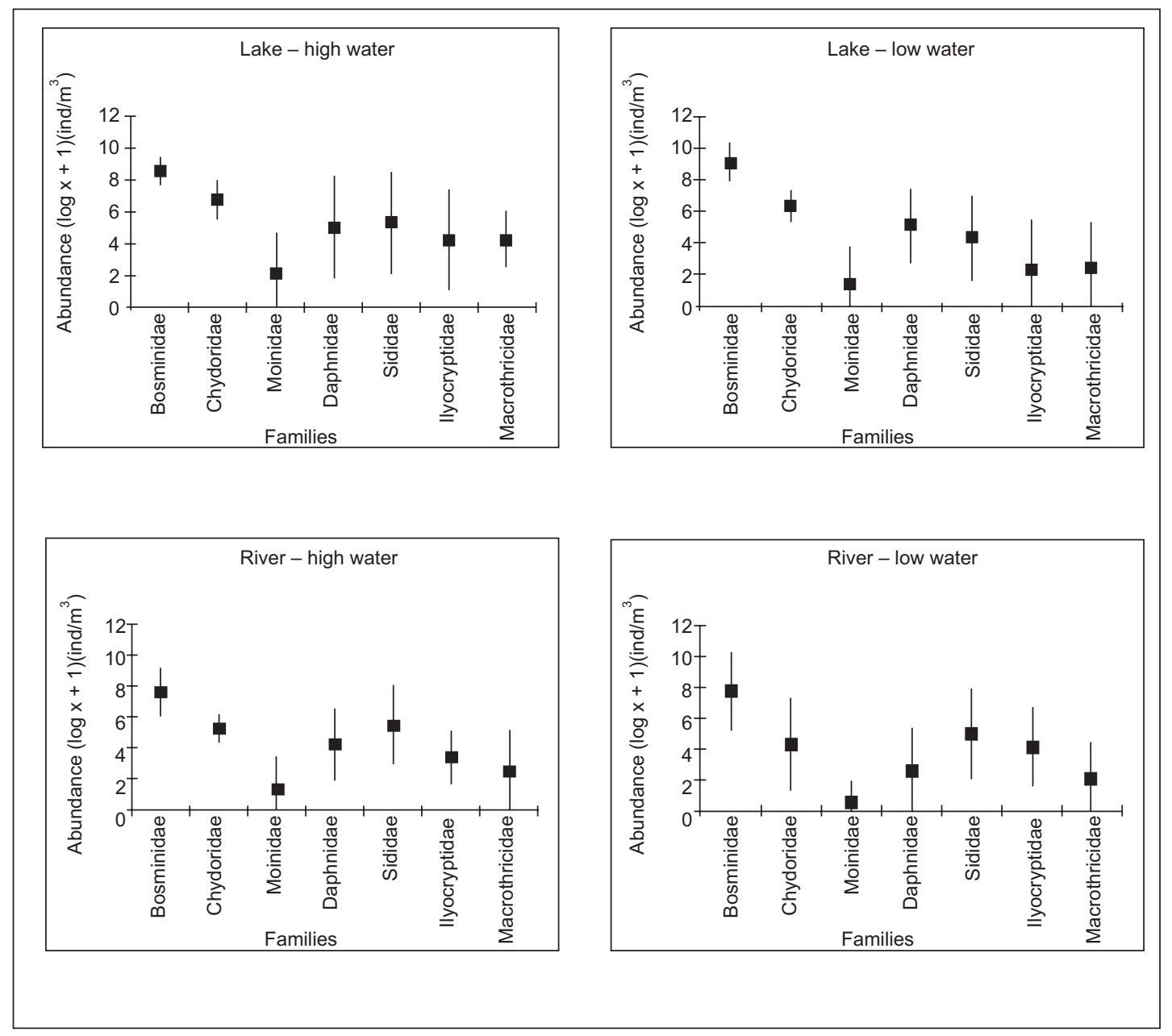

Fig. 4 - Mean and standard deviation of abundance of cladoceran families recorded in the lake and river during high and low water periods.

\section{Pearson's correlation}

The species considered in the correlation analyses for the two environments were those which were most abundant at all stations during the entire period: Alona dentifera, A. affinis affinis, Bosmina hagmani, B. tubicen, Bosminopsis deitersi, Diaphanosoma birgei, Phryxura dadayi, Ceriodaphnia cornuta, Ilyocryptus spinifer, and Macrothrix spinosa.

A higher number of correlations between the densities of these species and limnological variables, as well as the highest $r$ values, was found in the river (Table 2).

In the lake, only water level was important for the abundance of $A$. dentifera, since the highest densities of this species were related to the highest water levels. In the river, water level appeared significantly to influence abundances of $C$. cornuta and $P$. dadayi.

The highest densities of $C$. cornuta were also directly related to water transparency and electrical conductivity. Electrical conductivity also influenced the abundance of $B$. deitersi. The only variable which showed an inverse relationship to the cladocerans was dissolved oxygen. This factor significantly influenced the abundance of $P$. dadayi, the highest densities of this species being related to the lowest dissolved oxygen concentrations. This phenomenon may represent some development strategy of this species. 


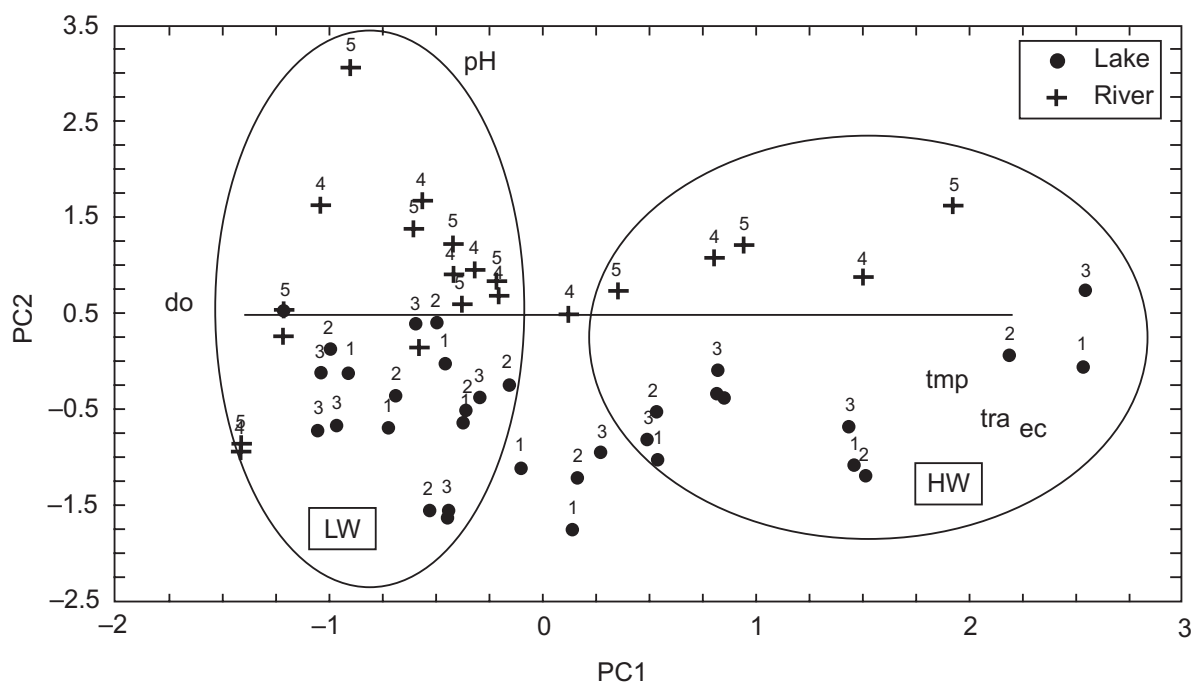

Fig. 5 - Principal components analysis for the environmental variables measured in the river and the lake. LW $=$ low water, $\mathrm{HW}=$ high water, $\mathrm{do}=$ dissolved oxygen, $\mathrm{ec}=$ electrical conductivity, $\mathrm{tmp}=$ water temperature and tra $=$ water transparency.

\section{DISCUSSION}

The dominant family recorded in the present study was Bosminidae, especially Bosminopsis deitersi. This species is frequently the most abundant cladoceran of the Paraná River floodplain (Paggi \& José De Paggi, 1990; Lansac-Tôha et al., 1997; Sendacz, 1997). Lima et al. (1998) also described it as numerically important in the Upper Paraná River. The numerical importance of bosminids in these environments may be related to the acid to neutral $\mathrm{pH}$ values. Equivalent $\mathrm{pH}$ levels were described as being favorable for development of bosminid populations in Amazonian black waters (Robertson \& Hardy, 1984), and in the Paraná floodplain (Lima et al., 1998).

In addition to the Bosminidae, the greater abundance of Chydoridae in the lake as opposed to Sididae in the river may be related to the presence of extensive banks of macrophytes, the preferred habitat of chydorids, in the lake. The predominance of chydorids among macrophytes was also observed by Valdivia \& Zambrano (1989) in a lake in Peru. Camargo et al. (1983) considered that large amounts of living biomass and detritus, originating mainly from decomposition of aquatic macrophytes, are an important source of organic matter for the environment, on which many consumers depend. Probably the Sididae were more important than the Chydoridae in the river because of the absence of vegetation along its banks. It is worth emphasizing that the highest cladoceran densities in the river were found in the region near the banks but without vegetation.

The results from the principal component analysis provided evidence of the homogenization of the environments, from the limnological variables studied. The analysis also showed that the system differed more in respect to the physical and chemical characteristics of the water column during the course of the year, than between environments. The only variable distinguishing the environments was $\mathrm{pH}$, mainly during low water. Thomaz et al. (1997) observed that during high water, a lesser degree of variation in the limnological factors of the Paraná River floodplain environments indicates that the flood pulse tends to homogenize those aquatic environments influenced by the river.

From the Pearson's correlation analysis we could verify more significant correlations between the densities of the main species and limnological factors in the river than in the lake. This suggests that those limnological variables studied probably influence cladoceran population structure more in the river than in the lake. Other factors such as the physical structure of the environment, or the amount of vegetation present along the shores, as well as biotic relationships such as competition and predation between populations appear to be more important in the dynamics of the main species in the lake. 
TABLE 2

Pearson's correlations between the limnological variables and densities of the principal taxa, in both environments studied ( $<$ 0.05). Significance for each environment according to Bonferoni's criterion (p < $\mathbf{0 . 0 5} / 16=0.03)($ Green, 1993). $\mathrm{L}=$ water level, $\mathrm{T}=$ water temperature, $\mathrm{Tr}=$ water transparency, $\mathrm{EC}=$ electrical conductivity, and DO = dissolved oxygen. Significant correlations are indicated in boldface.

\begin{tabular}{|c|c|c|c|c|c|c|c|c|c|c|c|c|}
\hline & \multicolumn{2}{|c|}{$\mathbf{L}(\mathbf{c m})$} & \multicolumn{2}{|c|}{$\mathbf{T}\left({ }^{\circ} \mathrm{C}\right)$} & \multicolumn{2}{|c|}{$\operatorname{Tr}(\mathbf{m})$} & \multicolumn{2}{|c|}{$\mathrm{EC}(\mu \mathrm{S} / \mathrm{cm})$} & \multicolumn{2}{|c|}{ DO (mg/L) } & \multicolumn{2}{|c|}{$\mathbf{p H}$} \\
\hline Taxa & $\mathbf{r}$ & $\mathbf{p}$ & $\mathbf{r}$ & $\mathbf{p}$ & $\mathbf{r}$ & $\mathbf{p}$ & $\mathbf{r}$ & $\mathbf{P}$ & $\mathbf{r}$ & $\mathbf{p}$ & $\mathbf{r}$ & $\mathbf{P}$ \\
\hline \multicolumn{13}{|c|}{ Lake } \\
\hline A. dentifera & 0.38 & 0.03 & 0.09 & 0.62 & 0.36 & 0.04 & 0.10 & 0.56 & -0.21 & 0.24 & 0.04 & 0.80 \\
\hline A. affinis affinis & -0.29 & 0.92 & -0.17 & 0.34 & -0.24 & 0.17 & -0.23 & 0.18 & 0.28 & 0.12 & 0.23 & 0.20 \\
\hline B. deitersi & -0.17 & 0.34 & 0.18 & 0.32 & -0.18 & 0.32 & 0.49 & 0.78 & 0.10 & 0.56 & 0.16 & 0.36 \\
\hline B. hagmani & -0.02 & 0.89 & 0.16 & 0.36 & 0.25 & 0.17 & 0.19 & 0.27 & -0.19 & 0.27 & -0.11 & 0.53 \\
\hline B. tubicen & -0.12 & 0.49 & 0.22 & 0.22 & 0.01 & 0.95 & -0.07 & 0.68 & 0.06 & 0.71 & -0.39 & 0.83 \\
\hline C. cornuta & 0.18 & 0.41 & 0.24 & 0.18 & 0.06 & 0.72 & 0.51 & 0.78 & -0.07 & 0.69 & 0.24 & 0.17 \\
\hline D. birgei & 0.19 & 0.29 & 0.35 & 0.04 & 0.12 & 0.49 & 0.22 & 0.21 & -0.16 & 0.36 & 0.20 & 0.25 \\
\hline I. spinifer & 0.35 & 0.05 & 0.25 & 0.17 & 0.24 & 0.18 & 0.09 & 0.61 & -0.15 & 0.38 & 0.17 & 0.35 \\
\hline M. spinosa & 0.35 & 0.04 & 0.21 & 0.24 & -0.02 & 0.99 & 0.19 & 0.28 & -0.34 & 0.052 & -0.01 & 0.99 \\
\hline P. dadayi & 0.86 & 0.63 & 0.11 & 0.53 & -0.06 & 0.72 & 0.87 & 0.63 & -0.07 & 0.42 & 0.14 & 0.44 \\
\hline \multicolumn{13}{|c|}{ River } \\
\hline A. dentifera & 0.14 & 0.53 & -0.01 & 0.95 & -0.08 & 0.71 & -0.01 & 0.96 & -0.36 & 0.11 & 0.09 & 0.67 \\
\hline A. affinis affinis & -0.20 & 0.38 & -0.15 & 0.51 & -0.36 & 0.11 & -0.25 & 0.28 & 0.19 & 0.40 & -0.19 & 0.39 \\
\hline B. deitersi & 0.07 & 0.76 & 0.41 & 0.06 & 0.44 & 0.04 & 0.45 & 0.03 & -0.21 & 0.35 & 0.36 & 0.10 \\
\hline B. hagmani & 0.23 & 0.31 & 0.45 & 0.04 & 0.43 & 0.051 & 0.15 & 0.51 & -0.28 & 0.22 & 0.11 & 0.62 \\
\hline B. tubicen & -0.31 & 0.18 & -0.19 & 0.39 & 0.07 & 0.76 & -0.18 & 0.42 & 0.21 & 0.38 & -0.09 & 0.69 \\
\hline C. cornuta & 0.75 & 0.01 & 0.27 & 0.23 & 0.52 & 0.02 & 0.78 & 0.01 & -0.29 & 0.20 & 0.09 & 0.67 \\
\hline D. birgei & -0.01 & 0.96 & -0.01 & 0.97 & 0.23 & 0.31 & 0.13 & 0.56 & -0.24 & 0.29 & -0.31 & 0.17 \\
\hline I. spinifer & -0.22 & 0.34 & -0.24 & 0.29 & -0.23 & 0.32 & -0.17 & 0.45 & 0.44 & 0.04 & 0.23 & 0.31 \\
\hline M. spinosa & -0.15 & 0.51 & -0.03 & 0.88 & -0.25 & 0.27 & -0.04 & 0.88 & -0.09 & 0.67 & 0.10 & 0.65 \\
\hline P. dadayi & 0.63 & 0.01 & 0.43 & 0.053 & 0.27 & 0.23 & 0.38 & 0.08 & -0.52 & 0.02 & -0.01 & 0.95 \\
\hline
\end{tabular}

Frutos (1996) observed that it is a difficult task to evaluate the factors responsible for the variation of zooplankton in environments which are subject or not to periodic flooding, in view of the fact that changes in population structure are defined not only by the dynamics of processes internal to the environments, but also by the addition and superposition of changes in the surrounding environments of the floodplain.

Acknowledgments - We would like to thank Drs. Sidinei Magela Thomaz, and Norma Segathi Hahn for suggestions, and $\mathrm{CNPq}$ and DBI/Nupélia for financial and logistical support. Dr. Janet W. Reid revised the English text.

\section{REFERENCES}

CAMARGO, A. F. M., ISHII, I. H. \& ESTEVES, F. A., 1983, Liberação de compostos orgânicos e inorgânicos para a coluna d'água durante o processo de decomposição de duas espécies de macrófitas aquáticas tropicais. An Sem. Reg. Ecol., São Carlos, 3: 87-99.

CAMPOS, J. C. R., LANSAC-TÔHA, F. A., NUNES, M. A., GARCIA, A. P. P. \& PRADO, F. R., 1996, Composição da comunidade zooplanctônica de três lagoas da ilha Porto Rico na planície de inundação do alto rio Paraná. Acta Limnologica Brasiliensia, 8: 183-194.

CORRALES de JACOBO, M. A. \& FRUTOS, S. M., 1985, Estudio preliminar del zooplancton de la laguna Sirena (Corrientes, Argentina). Physis, Secc. B., 43(104): 43-48. 
ELÍAS-GUTIÉRREZ, M., CIROZ-PÉREZ, J., GUTIÉRREZAGUIRRE, M. \& CERVANTES-MARTÍNEZ, A. A., 1997, Checklist of the littoral cladocerans from Mexico, with descriptions of five taxa recently recorded from the Neovolcanic Province. Hydrobiologia, 360: 63-73.

ELMOOR-LOUREIRO, L. M. A., 1997, Manual de identificação de cladóceros límnicos do Brasil, Brasília. Universa., $156 \mathrm{p}$.

FRUTOS, S. M., 1996, Zooplancton de la laguna turbia (isla del Cerrito) en la confluencia de los rios Paraná y Paraguay (Argentina). Rev. Brasil. Biol., 56(3): 569-580.

FUEM PADCT-CIAMB, 1994, Estudos ambientais na planície de inundação do alto rio Paraná no trecho compreendido entre a foz do rio Paranapanema e o reservatório de Itaipu. Universidade Estadual de Maringá, Maringá, 3v. Relatório anual do projeto. Apoio PADCTCIAMB.

GREEN, R. H., 1993, Application of repeated measures desing in environmental impact and monitoring studies. Anst. J. Ecol., 18: 81-98.

JUNK, W. J., BALLEY, P. B. \& SPARKS, R. E., 1989, The flood pulse concept in river-floodplain systems, In: D. P. Dodgee (ed.), Proccedings of the International large river Symposium. Can Spec. Publ. Fish. Aquat. Sci., 106: 110-127.

JUNK, W. J., 1980, Áreas Inundáveis - um desafio para a limnologia. Acta Amazonica, 10(4): 775-795.

KORÍNEK, V., 1981, Diaphanosoma birgei n. sp. (Crustacea, Cladocera). A new species from America an it's widely distribution species Diaphanosoma birgei ssp. lacustris n. spp. Can. J. Zool., 59(6): 1115-1121.

LANSAC-TÔHA, F. A., BONECKER, C. C., VELHO, L. F. M. \& LIMA, A. F., 1997, Composição, distribuição e abundância da comunidade zooplanctônica. In: A. E. A. M. Vazzoler, A. A. Agostinho \& N. S. Hahn (eds.), A Planície de Inundação do Alto Rio Paraná: Aspectos físicos, biológicos e sócio-econômicos. Editora da Universidade Estadual de Maringá, Maringá, PR, pp. 117-155.

LIMA, A. F., LANSAC-TÔHA, F. A., VELHO, L. F. M. \& BINI, L. M., 1998, Effect of limnological factors on spatial and temporal variation in abundance of microcrustacean zooplankton (Cladocera and Copepoda) in floodplain environments of the upper River Paraná, State of Mato Grosso do Sul, Brazil. Stud. Neotrop. Fauna Environ (in press).

MARGARITORA, F. G., MAGIN, E. \& PINEL-ALLOUL, B., 1875, Les cladocères littoraux de trois lacs des Laurentides à Saint-Hippolyte (Québec). Can. J. Zool., 53: 1898-1906.

PAGGI, J. C. \& JOSÉ DE PAGGI, S., 1990, Zooplâncton de ambientes lóticos e lênticos do rio Paraná médio. Acta Limnol. Brasil., 3: 685-719.

PAGGI, J. C., 1995, Crustacea Cladocera. In: E. C. Lopretto \& G. Tell (eds.), Ecossistemas de Aguas Continentales: Metodologia para su Estudio. Ediciones Sur, 3 ed. La Plata, pp. 909-951.
PATERSON, M., 1993, The distribuition of microcrustacea in the littoral zone of a freshwater lake. Hydrobiologia, 263: 173-183.

ROBERTSON, B. A. \& HARDY, E. R., 1984, Zooplankton of Amazonian lakes and rivers. In: H. Sioli, The Amazon: Limnologie and landscape ecology of a mighty tropical river and its basin. Dordrecht: Dr. W. Junk. Publishers. Monographie Biological, 56: 337-352.

RYBAK, M., RYBAK, J. I. \& TARWID, K., 1964, Differences in Crustacea Plankton based on the morphological charater of the littoral of the lakes. Komitet EkologicznyPolska Akademia Nauk., 12: 160-172.

SENDACZ, S., 1997, Zooplankton studies of floodplain lakes of the Upper Paraná River, São Paulo State, Brazil. Verh. Internat. Verein. Limnol., 26: 621-627.

SMIRNOV, N. N., 1974, Fauna of the USSR. Crustacea: Chydoridae. Jerusalém, Israel, Program for Scientific Translation, 1(2): 1-644.

SMIRNOV, N. N., 1992, The Macrothricidae of the world. The Hague: The Netherlands: SPB Academics. Guides to the identification of the microinvertebrates of the continental waters of the world, v.1.

SMIRNOV, N. N. \& DAVIS, C. C., 1973, Concernig some littoral Cladocera from Avalom Peninsula, Newfoundland. Can. J. Zool., 51: 65-68.

SMIRNOV, N. N. \& SANTOS-SILVA, E. N., 1995, Some littoral anomopods (Crustacea) from Central Amazônia. Hydrobiologia, 315: 227-230.

STATISTICA, 1996, Tulsa: Stat Soft, v. 3.

THOMAZ, S. M., ROBERTO, M. C. \& BINI, L. M., 1997, Fatores limnológicos abióticos e clorofila a: caracterização dos habitats e influências do pulso de inundação. In: A. E. A. M. Vazzoler, A. A. Agostinho \& N. S. Hahn (eds.), A Planície de Inundação do Alto Rio Paraná: aspectos físicos, químicos, biológicos e sócio-econômicos. Editora da Universidade Estadual de Maringá, Maringá, pp. 73-1-2.

THOMAZ, S. M., ROBERTO, M. C., LANSAC-TÔHA, F. A., ESTEVES, F. A. \& LIMA, A. F., 1992, Seasonal variation of some limnological factors of lagoa do Guaraná, a varzea lake of the high Rio Paraná, State of Mato Grosso do Sul, Brazil. Rev. Hydrobiol. Trop., 25(4): 269-276.

TWOMBLY, S. \& LEWIS JR., W. M., 1987, Zooplankton abundance and species composition in Laguna la Orsinera, a Venezuelan floodplain lake. Arch. Hydrobiol. Suppl., 79(1): 87-107.

VALDIVIA, L. \& ZAMBRANO, F., 1989, Cladóceros de la laguna de Paca, Junín: relaciones ecológicas entre habitat y especie. Boletin de Lima., 64: 83-89.

WHITESIDE, M. C., WILLIAMS, J. B. \& WHITE, C. P., 1978, Seasonal abundance and pattern of chydorid, cladocera in mud and vegetative habitats. Ecology, 59(6): 1177-1188. 